\title{
ANALYSIS SCHEDULING PROJECT USING CPM METHOD (Case study : Project of the Surabaya Caspian Tower Apartment)
}

\author{
Harjian Maprilana ${ }^{1}$, \\ Faculty of Engineering, Narotama University Surabaya \\ maprilanahariian@gmail.com \\ Koespiadi ${ }^{2}$ \\ Faculty of Engineering Narotama University Surabaya
}

\begin{abstract}
The success and failure of project implementation is often caused by poor planning and ineffective controls, so that project activities experience various obstacles such as the late completion of the project, the decline in the quality of work and the swelling of implementation costs. Project management is carried out to manage the project from the beginning of the project until the completion of the project properly. The case study in this study is PT. PP (Persero) Tbk. as the executing element of the construction work, it is in charge of organizing the construction of the Surabaya Caspian Tower Apartment in East Java. The CPM (Critical Path Method) method is used to find out how long a project has been completed and look for possible acceleration of project time. From the research using the CPM method, it can be seen that the normal duration of project completion is 453 days which can be optimized to 350 days. This can be done by giving special attention to activities included in the critical path and accelerating some activities by increasing the number of workers
\end{abstract}

Keywords : project, CPM, duration, critical path

\section{INTRODUCTION}

Companies must make good planning to get efficient time so as to minimize the cost of implementing the project. Good scheduling management is needed in a plan. This relates to human resource needs and the tools used in project activities. These resource requirements will play a major role in the cost efficiency of project implementation because there are times when these resources are not utilized but financing continues.

In working on the project, PT PP (Persero) still uses the S curve method in the process. Companies sometimes experience problems where the completion of work is not in accordance with the initial planned time. There are some jobs that experience setbacks due to poor planning. This results in a bad image for the company because it is unable to complete a project at the specified time. Companies can also experience a swelling of costs if the project completion time is not as agreed upon. The project completion time can also be delayed due to poor weather conditions. Therefore the company hopes that project activities can complete the work earlier than the specified time. As a result of bad weather also affects the development of projects that are less experienced. In this case, the duration of project completion is needed to find out how much time is needed in completing a project and analyze the acceleration of the duration of activities with the CPM (Critical Path Method) method or also called the critical path method. 


\section{Formulation of the problem}

Some of the problems faced are as follows:

1. What is the optimal duration of the Caspian Tower Apartment project completion using the CPM method?

2. What jobs are classified as critical work in the Caspian Tower Apartment project?

3. What is the result of the comparison of project completion time between the $S$ curve method and the CPM method?

\section{Scope of problem}

The limitation of the problem is as follows:

1. Researchers are guided by conducting research based on data from PT PP (Persero) Tbk

2. The CPM method is used to find out the work that is included in the critical path which plays a role in measuring the company's capacity

3. Discussion of rejecting the capacity using the CPM method is limited to planning in the form of a performance measurement tool.

4. Data used is only data that covers the CPM method perspective, namely project scheduling

\section{Research purposes}

The research scheduling analysis of this project aims, among others, to:

1. Reviewing the Surabaya Caspian Tower apartment construction project to get optimal time in completion.

2. Understand what work is classified as critical work on the project at the Caspian Tower Surabaya.

3. Analyze the comparison of project completion time between the $S$ curve method and the CPM method.

\section{Benefits of research}

Research on the Tower Caspian Surabaya apartment project was carried out to convey the following benefits:

1. Able to better control the Caspian Tower apartment project if using the CPM method.

2. Able to improve understanding of the development of a project using the CPM method.

3. Being able to apply the CPM method in a project in order to achieve optimal time in the completion of a project.

4. Can implement the CPM method on projects that are being implemented to get maximum results in the development process.

5. Can analyze project activities in accordance with written guidelines so that the project that runs can be carried out optimally in terms of time which has an impact on adding literature studies in the field of development in higher education.

6. Useful as a consideration for how well the system and lecture material have been carried out to date with the state of the project.

\section{LITERATURE REVIEW Network Planning}

Network planning is a management tool that allows broader and more complete planning and supervision of a project. (SoetomoKajatmo, 1977). Network planning is one of the models used in project organizers whose products are information about activities in the project's network diagram. (TubagusHaedar Ali, 1995). Network planning in principle is a dependency relationship between work parts (variables) that are described / visualized in a network diagram. (SofwanBadri, 1997).Following are the details of the usefulness of network planning:

a. Provide overall planning, scheduling and control activities. 
b. Can estimate the time, costs and resources needed.

c. As project documentation

d. Knowing critical activities

e. As a data communication tool, problems and project objectives.

There are 2 kinds of diagrams known in network planning, the first is the network diagram version CPM and PERT, while the second is a diagram often known as the precedence diagram. The precedence diagram shows no events, while the CPM / PERT version of the network diagram is known for events at the beginning of each activity and at the end of each activity. The network planning prerequisites that must be met in the implementation of the project are:

1. The model must be complete

Network planning is an information model of activities that is in the network diagram. Resource information is also needed, which aims to provide the right information so that the resources needed are always ready to use.

2. The model must match.

Network diagrams of each project are different, because it requires a diagram that fits the problem at hand.

3. The assumption used is right

Network planning as a planning method inevitably has to use assumptions, because the success of network planning depends on the accuracy of the assumptions used.

4. Acting attitude

Support is needed from the attitude of the implementers so that project organizers can succeed.

\section{Project and Activity Relations}

The project is a track of activity that starts at the beginning and finishes at a final moment, namely when the project objectives are achieved (Tubagus $\mathrm{H} \mathrm{1997;7).} \mathrm{If} \mathrm{the} \mathrm{project} \mathrm{is}$ considered as a system, then the input is the initial state and the output is the final state while the process is technology. The activity is essentially an input interaction process that is a resource with the skills to produce output, in the form of certain products. So activities can also be said to be activities which are components of a structured system forming a project, while a project is the result of integration of several activities.

\section{CPM (Critical Path Method) Method}

Critical Path Method (CPM) or often known as critical path method, according to Levin and Kirkpatrick (1972) is a method for planning and supervising projects is the system most widely used among all other systems that use the principle of network formation. The CPM method is widely used by construction projects. This method can be used if the duration of the work is known and does not fluctuate too much.

Whereas Siswanto (2007) defines CPM as a project management model that prioritizes cost as an object that is analyzed by CPM is a network analysis that seeks to optimize the total cost of the project through a reduction in total project completion time. Using the CPM method can save time in completing various stages of a project.

\section{Network}

The work network is a network that consists of a series of activities to complete a project based on the order and dependence of one activity with other activities. So that a job cannot be started if the previous activity has not been completed.According to Hayun (2005) the symbols used in describing a network are as follows:

1) (arrow / bow), expressing an activity needed by the project. This activity is defined as things that require duration (a certain period of time). There is no time scale, arrows only indicate the beginning and end of an activity.

2) (small circle / node / node) states an event or event. 
3) (dotted line arrows) indicate pseudo activity (dummy activity). This dummy does not have a duration, because it does not consume resources (only limits the start of activities). The difference with ordinary activities is that dummy activities do not take time and resources, so the activity time and cost are zero.

4) (thick arrows) express activities on the critical path.

Hayum (2005) mentions, these symbols are used by following the rules as follows:

1) Among the same two events (events), only one arrow can be drawn.

2) The name of an activity is expressed by letter or by the event number.

3) Activities must flow from low numbered events to high numbered events.

4) The diagram only has an initial event and a terminal event.

According to Suharto (1999), here are the steps in developing a CPM network:

1) Assessing and identifying the project environment, outlining, solving it into activities or groups of activities which are components of the project.

2) Reordering the components in item 1, becomes a chain in a sequence that matches the logic of dependence.

3) Provide an estimate of the time period for each activity resulting from the decomposition of the project scope.

4) Identify the critical path (critical path) and float on the network.

\section{Duration of Time Activities}

The duration of activities in the networking method is the length of time needed to carry out activities from beginning to end. The time period is generally expressed in units of hours, days or weeks. The duration calculation in the CPM method is used to estimate the activity completion time, that is by single duration estimate. This method is done if the duration can be known accurately and not too fluctuating. The formula used to calculate the duration of the activity is (Suharto, 1999).

Information:

$$
D=\frac{V}{\operatorname{Pr} . N}
$$

$\mathrm{D}=$ duration of activity

$\mathrm{V}=$ volume of activity

$\mathrm{Pr}=$ average work productivity

$\mathrm{N}=$ number of labor and equipment

\section{Critical Path}

The critical path according to Render and Jay (2006) is a series of activities - activities of a project that cannot be delayed by the time of implementation and show relationships that are interrelated with each other. The more critical paths in a project, the more activities that must be monitored. The accumulation of the longest duration in the critical path will be used as an estimation of the overall project completion time. The critical path is obtained from a network diagram that shows the relationship and sequence of activities in a project.

The logic of dependence on these activities can be stated as follows:

1) If activity $A$ must be completed before activity $B$ can begin and activity $C$ can begin after activity $B$ is completed, the relationship of these activities can be seen in Figure 2.3.1

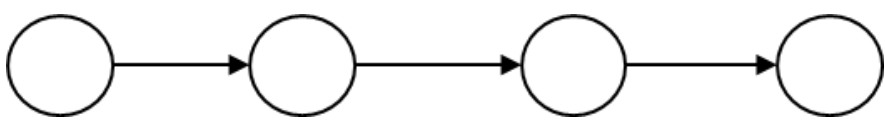

A B C

Figure 2.3 Activity A precursor to activity B \& activity B precursor to activity C (Source: Render \& Jay, 2006) 
2) Activities $A$ and $B$ must be completed before activity $C$ can begin, the relationship of activities can be seen in Figure 2.3.2

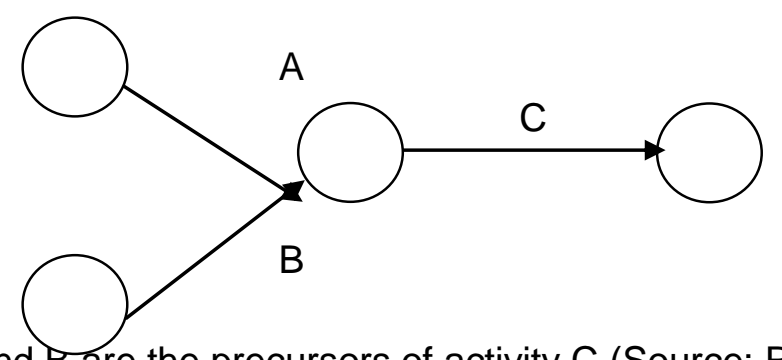

Figure 2.4 Activities A and B are the precursors of activity C (Source: Render \& Jay, 2006) 3 ) If activities $A$ and $B$ must begin before activities $C$ and $D$, the activity relationship can be seen in Figure 2.3.3

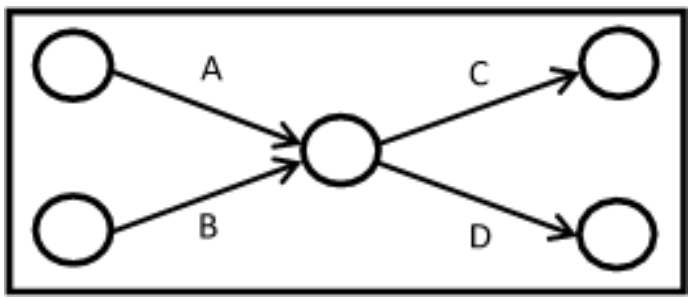

Figure 2.5 A \& B activities are the precursors of $C \& D$ activities

(Source: Render \& Jay, 2006)

4) If activities $A$ and $B$ must be completed before activity $C$ can begin, but $D$ can already be started if activity $B$ has been completed, the relationship of the activity can be seen in Figure 2.3.4
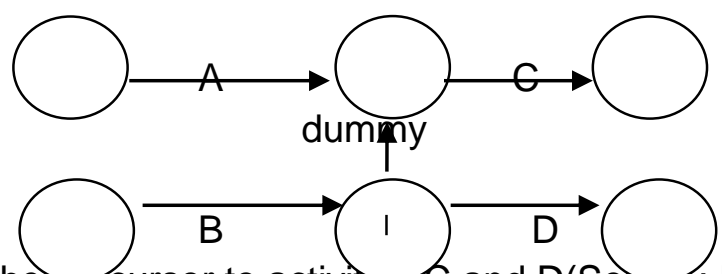

Figure 2.6 Activity B is the precursor to activites $C$ and D(Soure: Render \& Jay, 2006)

The dummy function (--- $\square$ ) above is to move immediately (in accordance with the direction of the arrow) information about the completion of activity $B$.

5) If activities $A, B$, and $C$ start and finish in the same circle of events, then the activity relationship can be seen in Figure 2.3.4
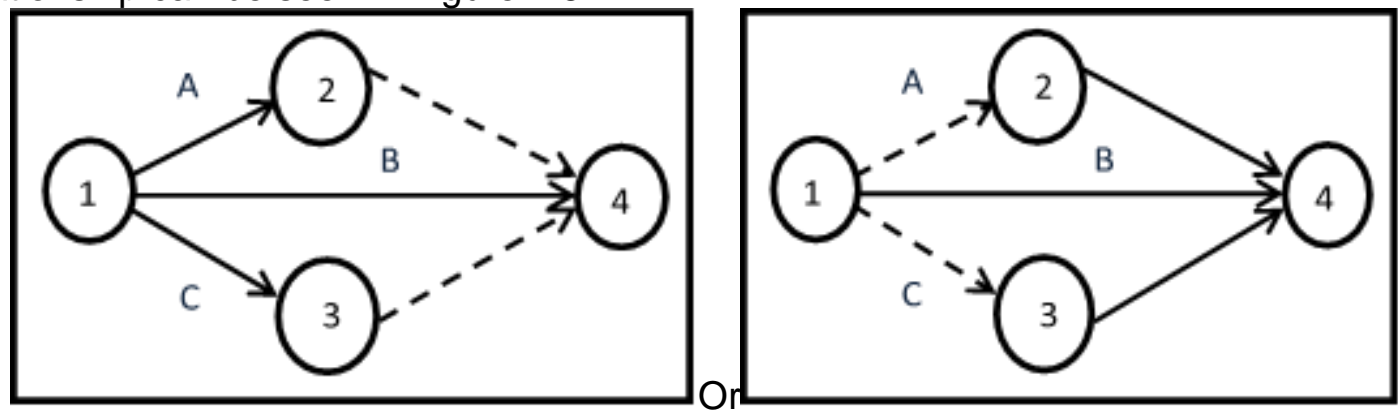

Figure 2.7 Activities A, B, and C start and finish in the same event Source: Render \& Jay, 2006 


\section{Activity Schedule}

In order to know the critical path we calculate two start and end times for each activity, as follows:

1) Earliest start - ES, that is, the previous time an activity can begin, assuming all predecessors have finished.

2) The previous finish (earliest finish - EF), ie the previous time an activity can be completed.

3) Last start (latest start - LS), which is the last time an activity can begin so as not to delay the completion of the entire project.

4) The final finish (latest finish - LF), which is the last time an activity can be completed so as not to delay the completion of the entire project.

In a project, the activity schedule can be seen in Figure 2.3.5

ES A EF

LS D LF

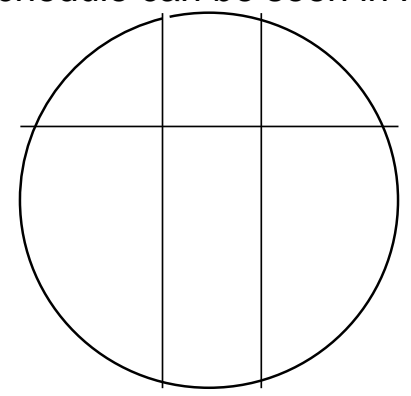

Figure 2.8 Overview of project activities

Information:

A = Name of activity

$\mathrm{D}=$ Duration of an activity

$\mathrm{ES}=$ Earliest start

LS $=$ Latest start

$\mathrm{EF}=$ Earliest finish

$\mathrm{LF}=$ Latest Finish

Activity barriers can occur in the implementation of a project, for that there must be a slack time in each activity. Slack (slack time) time is the free time each activity has to be able to be delayed without causing overall project delay. The slack time can be formulated as follows:

Slack $=$ LS - ES or Slack $=$ LF - EF Description:

Slack $=$ Free time $\mathrm{LS}=$ Latest start

$\mathrm{ES}=$ Earliest start

$\mathrm{LF}=$ Latest Finish

$\mathrm{EF}=$ Earliest finish

\section{METHODOLOGY}

In the method of data collection, there are some data needed to become the basic material in this study. The data includes project implementation data, time data for each job, human resource needs data, work tool requirements data, cost data during work and other data related to the needs of this research. 


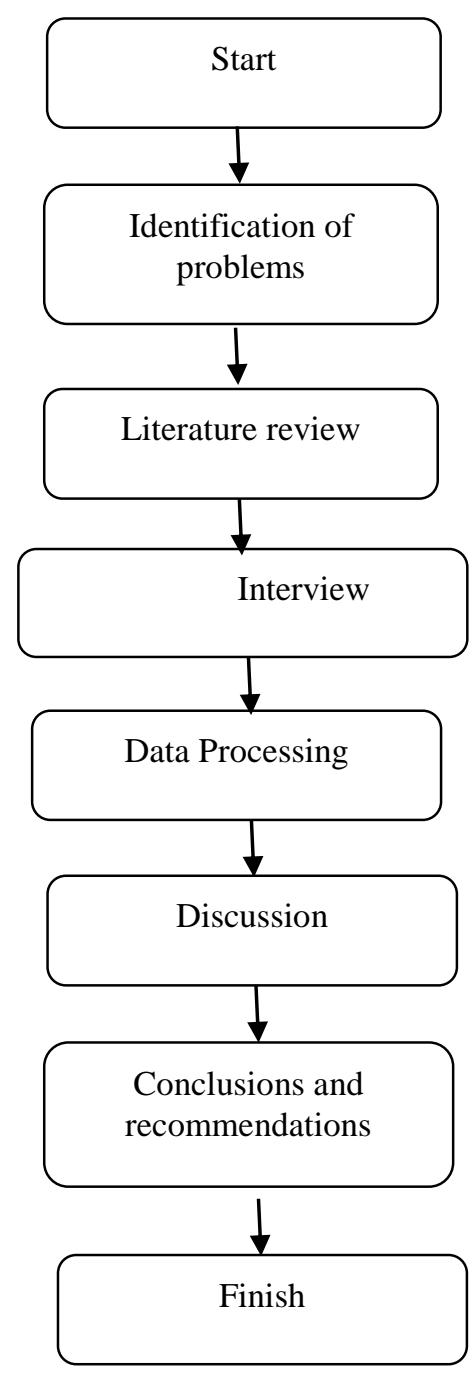

Figure 3.1 Research Framework

\section{RESULTS AND DISCUSSION}

\section{Data collection}

Based on the research that has been done by the company, some data is used in processing data. The data includes activity type data, activity sequence data and normal project duration data. These data are obtained from the contractor, in this case PT. PP (Persero) Tbk. which is secondary data obtained from company documents and based on interviews with the leaders and project staff concerned.

Activity Type Data

The data on the types of activities in the Surabaya Caspian Tower Apartment Construction Project were obtained from the results of company interviews and project work schedule data. The data used to compile the relationship between activities and the duration of each activity is obtained from the company through an interview process and data on existing project activities. This data is the data on the relationship between project activities and other activities which are arranged in the order of predecessors. Data on the types of project activities can be seen in table 4.1. 
Table 4.1 Item Activities for Construction of the Caspian Tower Apartment Surabaya

\begin{tabular}{|c|c|c|c|c|c|}
\hline \multirow{2}{*}{ No } & \multirow{2}{*}{ Pekerjaan } & \multirow{2}{*}{ Predecessors } & \multirow{2}{*}{ Durasi } & \multicolumn{2}{|c|}{ Tanggal Pengerjaan } \\
\hline & & & & Mulai & Selesai \\
\hline & Durasi Total & & 453 & 23 Juli 2018 & 19 Oktober 2019 \\
\hline 1 & Pekerjaan Lantai G round Floor & & & & \\
\hline A1 & Pekerjaan dinding & LT $2(A)+63$ HARI & 202 & 30 Desember 2018 & 20 Juli 2019 \\
\hline B1 & Pekerjaan plafond & $\mathrm{A} 1$ & 167 & 14 April 2019 & 28 September 2019 \\
\hline $\mathrm{C} 1$ & Pekerjaan Lantai & $\mathrm{B} 1, \mathrm{~F} 1$ & 181 & 24 Maret 2019 & 21 September 2019 \\
\hline D1 & Pekerjaan Pintu & $\mathrm{A} 1, \mathrm{C} 1$ & 48 & 07 Juli 2019 & 24 Agustus 2019 \\
\hline $\mathrm{E} 1$ & Pekerjaan Sanitari & $\mathrm{C} 1, \mathrm{D} 1$ & 83 & 28 Juli 2019 & 19 Oktober 2019 \\
\hline $\mathrm{F} 1$ & Raill & A1 & 118 & 16 Juni 2019 & 12 Oktober 2019 \\
\hline 2 & Pekerjaan Lantai 2 & & & & \\
\hline $\mathrm{A} 2$ & Pekerjaan dinding & LT $3(A)+28$ HARI & 188 & 28 Oktober 2018 & 04 Mei 2019 \\
\hline $\mathrm{B} 2$ & Pekerjaan plafond & $\mathrm{A} 2$ & 97 & 13 Januari 2019 & 20 April 2019 \\
\hline $\mathrm{C} 2$ & Pekerjaan Lantai & $B 2, F 2$ & 83 & 27 Januari 2019 & 20 April 2019 \\
\hline $\mathrm{D} 2$ & Pekerjaan Pintu & $\mathrm{A} 2, \mathrm{C} 2$ & 13 & 21 April 2019 & 04 Mei 2019 \\
\hline E2 & Pekerjaan Sanitari & $\mathrm{C} 2, \mathrm{D} 2$ & 13 & 05 Mei 2019 & 18 Mei 2019 \\
\hline $\mathrm{F} 2$ & Raill & $\mathrm{A} 2$ & 132 & 30 Desember 2018 & 11 Mei 2019 \\
\hline 3 & Pekerjaan Lantai 3 & & & & \\
\hline $\mathrm{A} 3$ & Pekerjaan dinding & LT $4(\mathrm{~A})+28 \mathrm{HARI}$ & 188 & 30 September 2018 & 06 April 2019 \\
\hline B3 & Pekerjaan plafond & A3 & 62 & 02 Desember 2018 & 02 Februari 2019 \\
\hline $\mathrm{C3}$ & Pekerjaan Lantai & $\mathrm{B} 3, \mathrm{F3}$ & 90 & 23 Desember 2018 & 23 Maret 2019 \\
\hline D3 & Pekerjaan Pintu & $\mathrm{A} 3, \mathrm{C} 3$ & 41 & 17 Maret 2019 & 27 April 2019 \\
\hline E3 & Pekerjaan Sanitari & $\mathrm{C} 3, \mathrm{D} 3$ & 51 & 14 Maret 2019 & 04 Mei 2019 \\
\hline F3 & Raill & $\mathrm{A3}$ & 90 & 06 Januari 2019 & 06 April 2019 \\
\hline 4 & Peke rjaan Lantai 4 & & & & \\
\hline $\mathrm{A} 4$ & Pekerjaan dinding & LT $5(A)+41$ HARI & 188 & 02 September 2018 & 09 Maret 2019 \\
\hline B4 & Pekerjaan plafond & A4 & 62 & 04 Novem ber 2018 & 05 Januari 2019 \\
\hline $\mathrm{CA}$ & Pekerjaan Lantai & $\mathrm{B} 4, \mathrm{~F} 4$ & 104 & 25 November 2018 & 09 Maret 2019 \\
\hline D4 & Pekerjaan Pintu & $\mathrm{A} 4, \mathrm{C} 4$ & 20 & 10 Maret 2019 & 30 Maret 2019 \\
\hline E4 & Pekerjaan Sanitari & $\mathrm{CA}, \mathrm{D} 4$ & 41 & 24 Maret 2019 & $04 \mathrm{Mei} 2019$ \\
\hline $\mathrm{F} 4$ & Raill & A4 & 153 & 04 November 2018 & 06 April 2019 \\
\hline 5 & Pekerjaan Lantai 5 & & & & \\
\hline A5 & Pekerjaan dinding & - & 222 & 23 Juli 2018 & 02 Maret 2019 \\
\hline $\mathrm{B} 5$ & Pekerjaan plafond & A5 & 111 & 11 November 2018 & 02 Maret 2019 \\
\hline $\mathrm{C5}$ & Pekerjaan Lantai & $\mathrm{B} 5, \mathrm{F5}$ & 118 & 21 Oktober 2018 & 16 Februari 2019 \\
\hline D5 & Pekerjaan Pintu & $\mathrm{A} 5, \mathrm{C} 5$ & 20 & 17 Februari 2019 & 09 Maret 2019 \\
\hline E5 & Pekerjaan Sanitari & C5,D5 & 48 & 10 Februari 2019 & 30 Maret 2019 \\
\hline $\mathrm{F} 5$ & Raill & A5 & 230 & 02 Septem ber 2018 & 20 April 2019 \\
\hline
\end{tabular}

\section{Data processing}

\section{CPM (Critical Path Method) Method}

In scheduling using the CPM method must begin with making a network diagram. Network diagram. The network diagram describes the activities, types of activities, predecessors and duration of work.

\section{Compile the Network Diagram}

Network diagrams that describe the relationship between work on the Surabaya Caspian Tower Project can be compiled based on the relationship data between work and planned time of UPER (Estimated Age). 

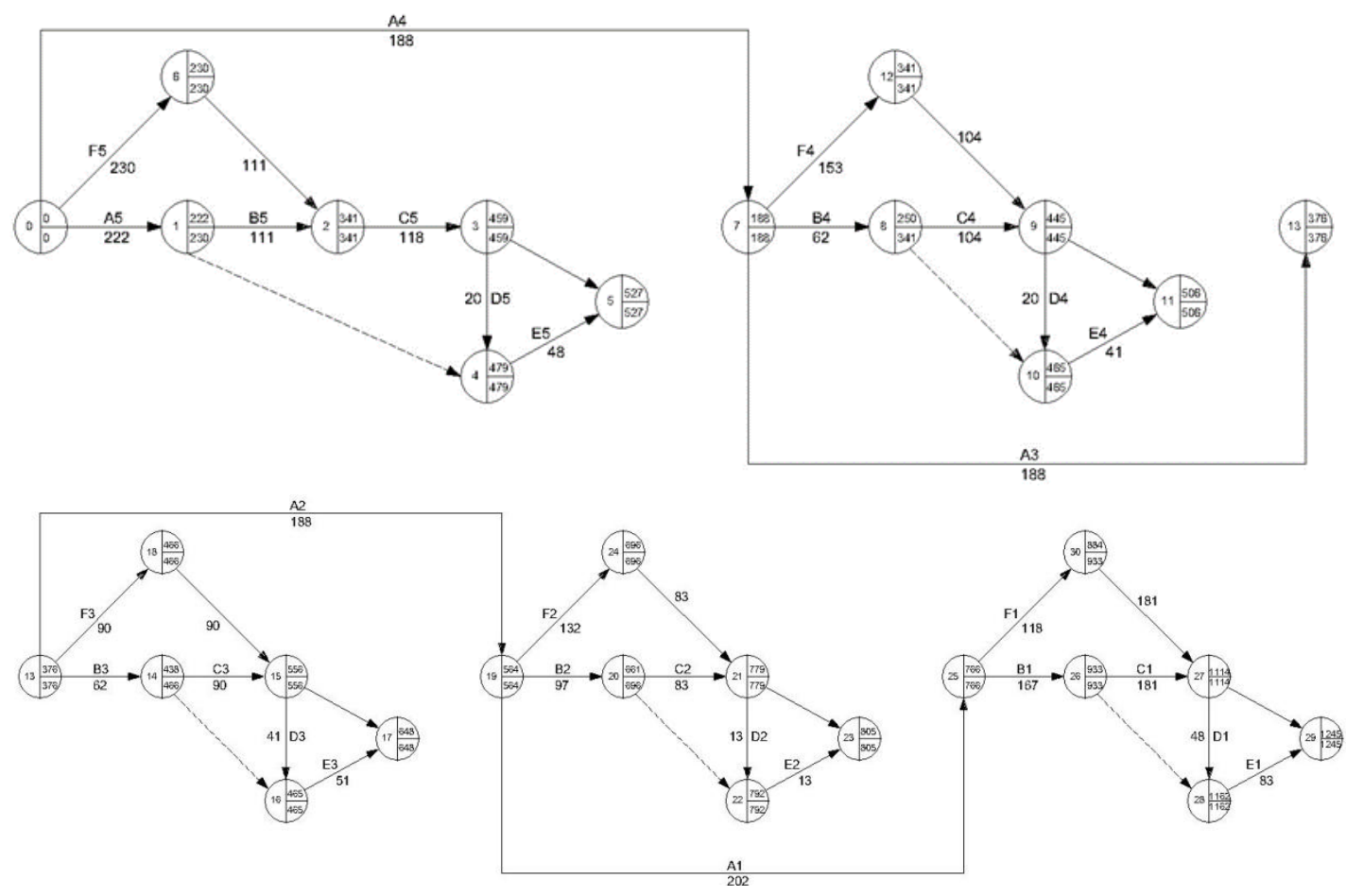

Figure 4.1 Network of Initial Duration Charts in the Surabaya Caspian Apartment Project

\section{Calculating SPA, SPL and Time Grace Between Activities}

At this stage, the SPA calculation (the earliest time), the SPL (the most recent time) and the grace period (slack) for each project work are carried out. This calculation aims that critical activities on a network diagram can be determined and this calculation is done manually using Ms. software. Excel. Where SPA and SPL are calculated sequentially from the smallest number to the most maximal number while the SPL is calculated starting from the maximum number of countdown to the smallest number. Following is the formula for calculating SPA, SPL and deadline:

$S P A j=S P A i+L$

SPLi $=$ SPLj - L

Timeliness $($ Slack $)=$ SPLI - SPAj

From the calculation formula, the SPA calculation, SPL and the grace period of the relationship data between activities can be seen in table 4.3: 
Table 4.3 Calculation of SPA, SPL and Timelines for the Caspian Surabaya Apartment

\begin{tabular}{|c|c|c|c|}
\hline \multirow{2}{*}{ KODE AKTIVITS } & SPA & SPL & Tenggang Waktu (Slack) \\
\hline A5 & 0 & 0 & 0 \\
\hline B5 & 222 & 230 & 8 \\
\hline C5 & 0 & 0 & 0 \\
\hline D5 & 0 & 0 & 0 \\
\hline E5 & 0 & 0 & 0 \\
\hline F5 & 0 & 0 & 0 \\
\hline A4 & 0 & 0 & 0 \\
\hline B4 & 250 & 341 & 91 \\
\hline C4 & 0 & 0 & 0 \\
\hline D4 & 0 & 0 & 0 \\
\hline E4 & 0 & 0 & 0 \\
\hline F4 & 0 & 0 & 0 \\
\hline A3 & 0 & 0 & 0 \\
\hline B3 & 438 & 466 & 28 \\
\hline C3 & 0 & 0 & 0 \\
\hline D3 & 0 & 0 & 0 \\
\hline E3 & 0 & 0 & 0 \\
\hline F3 & 0 & 0 & 0 \\
\hline A2 & 0 & 0 & 0 \\
\hline B2 & 661 & 696 & 35 \\
\hline C2 & 0 & 0 & 0 \\
\hline D2 & 0 & 0 & 0 \\
\hline E2 & 0 & 0 & 0 \\
\hline F2 & 0 & 0 & 0 \\
\hline A1 & 0 & 0 & 0 \\
\hline B1 & 0 & 0 & 0 \\
\hline C1 & 0 & 0 & 0 \\
\hline D1 & 0 & 0 & 49 \\
\hline E1 & 0 & 0 & 0 \\
\hline F1 & 884 & 933 & 0 \\
\hline & & & 0 \\
\hline
\end{tabular}

\section{Determine the Critical Path}

Critical trajectory can be determined by looking at the track with the longest working life of all existing paths. Activities that have a high level of supervision can be determined by identifying the critical trajectory. Activities that enter the critical path can be seen in the network diagram that has been made in Figure 4.1.

\section{Determining Accelerated Activities}

Accelerated activities are activities that are on the critical path. With the acceleration of activities it is expected to save time in project completion. The following is the acceleration of the duration of activities which can be seen in table 4.4: 
Table 4.4 Determining Accelerated Activities in the Surabaya Caspian Tower Apartment Project

\begin{tabular}{|c|c|c|c|c|c|}
\hline \multirow{2}{*}{ No } & \multirow{2}{*}{ Pekerjaan } & \multirow{2}{*}{ Predecessor } & \multirow{2}{*}{ Durasi } & \multicolumn{2}{|c|}{ Tangal Pengerjaan } \\
\hline & & & & Mulai & Selesai \\
\hline & Durasi Total & & 350 & 23 Juli 2018 & 08 Juli 2019 \\
\hline 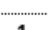 & & & & & \\
\hline A1 & Pekerjaan dinding & LT $2(A)+7$ HARI & 188 & 20 Agustus 2018 & 24 Februari 2019 \\
\hline B1 & Pekerjaan plafond & A1 & 62 & 17 Februari 2019 & 20 Ap ril 2019 \\
\hline $\mathrm{C} 1$ & Pekerjaan Lantai & $\mathrm{B} 1, \mathrm{~F} 1$ & 83 & 24 Maret 2019 & 15 Juni 2019 \\
\hline D1 & Pekerjaan Pintu & $\mathrm{A} 1, \mathrm{C} 1$ & 20 & 07 Mei 2019 & 27 Mei 2019 \\
\hline E1 & Pekerjaan Sanitari & $\mathrm{C} 1, \mathrm{D} 1$ & 41 & 28 Mei 2019 & 08 Juli 2019 \\
\hline $\mathrm{F} 1$ & Raill & A1 & 90 & 30 November 2018 & 28 Februari 2019 \\
\hline 2 & Pekerjaan Lantai 2 & & & & \\
\hline A2 & Pekerjaan dinding & LT $3(A)+7$ HARI & 188 & 13 Agustus 2018 & 17 Februari 2019 \\
\hline B2 & Pekerjaan plafond & A2 & 97 & 20 November 2018 & 25 Februari 2019 \\
\hline $\mathrm{C} 2$ & Pekerjaan Lantai & $\mathrm{B} 2, \mathrm{~F} 2$ & 83 & 12 Februari 2019 & 06 Mei 2019 \\
\hline $\mathrm{D} 2$ & Pekerjaan Pintu & $\mathrm{A} 2, \mathrm{C} 2$ & 13 & 21 Maret 2019 & 03 April 2019 \\
\hline$E 2$ & Pekerjaan Sanitari & $\mathrm{C} 2, \mathrm{D} 2$ & 13 & 03 April 2019 & 16 April 2019 \\
\hline $\mathrm{F} 2$ & Raill & A2 & 132 & 20 Okto ber 2018 & 01 Maret 2019 \\
\hline 3 & Pekerjaan Lantai 3 & & & & \\
\hline $\mathrm{A} 3$ & Pekerjaan dinding & LT 4 (A) + 7 HARI & 188 & 06 Agustus 2018 & 10Februari 2019 \\
\hline B3 & Pekerjaan plafond & A3 & 62 & 10 Desember 2018 & 10 Februari 2019 \\
\hline $\mathrm{C3}$ & Pekerjaan Lantai & $\mathrm{B} 3, \mathrm{F3}$ & 90 & 16 Januari 2019 & 16 April 2019 \\
\hline D3 & Pekerjaan Pintu & $\mathrm{A} 3, \mathrm{C} 3$ & 41 & 08 Maret 2019 & 18 April 2019 \\
\hline E3 & Pekerjaan Sanitari & $\mathrm{C} 3, \mathrm{D} 3$ & 51 & 28 Februari 2019 & 20 April 2019 \\
\hline $\mathrm{F} 3$ & Raill & $\mathrm{A} 3$ & 90 & 15 November 2018 & 13 Februari 2019 \\
\hline 4 & Pekerjaan Lantai 4 & & & & \\
\hline $\mathrm{A} 4$ & Pekerjaan dinding & LT $5(A)+7$ HARI & 188 & 30 Juli 2018 & 03 Februari 2019 \\
\hline B4 & Pekerjaan plafond & A4 & 62 & 05 Desember 2018 & 05 Februari 2019 \\
\hline $\mathrm{C} 4$ & Pekerjaan Lantai & $\mathrm{B} 4, \mathrm{~F} 4$ & 104 & 10 Desember 2018 & 24 Maret 2019 \\
\hline $\mathrm{D} 4$ & Pekerjaan Pintu & $\mathrm{A} 4, \mathrm{C} 4$ & 20 & 10 Maret 2019 & 30 Maret 2019 \\
\hline$E 4$ & Pekerjaan Sanitari & $\mathrm{C} 4, \mathrm{D} 4$ & 41 & 15 Maret 2019 & 25 April 2019 \\
\hline $\mathrm{F} 4$ & Raill & A4 & 118 & 080 kto ber 2018 & 03 Februari 2019 \\
\hline 5 & Pekerjaan Lantai 5 & & & & \\
\hline A5 & Pekerjaan dinding & - & 188 & 23 Juli 2018 & 27 Januari 2019 \\
\hline B5 & Pekerjaan plafond & A5 & 62 & 01 Desember 2018 & 01 Februari 2019 \\
\hline $\mathrm{C} 5$ & Pekerjaan Lantai & B5, F5 & 104 & 11 Desember 2018 & 25 Maret 2019 \\
\hline D5 & Pekerjaan Pintu & $\mathrm{A} 5, \mathrm{C} 5$ & 20 & 05 Maret 2019 & 25 Maret 2019 \\
\hline E5 & Pekerjaan Sanitari & $\mathrm{C} 5, \mathrm{D} 5$ & 41 & 10 Maret 2019 & 20 April 2019 \\
\hline F5 & Raill & A5 & 118 & 02 September 2018 & 29 Desember 2018 \\
\hline
\end{tabular}

The network diagram from table 4.4 can be seen below:

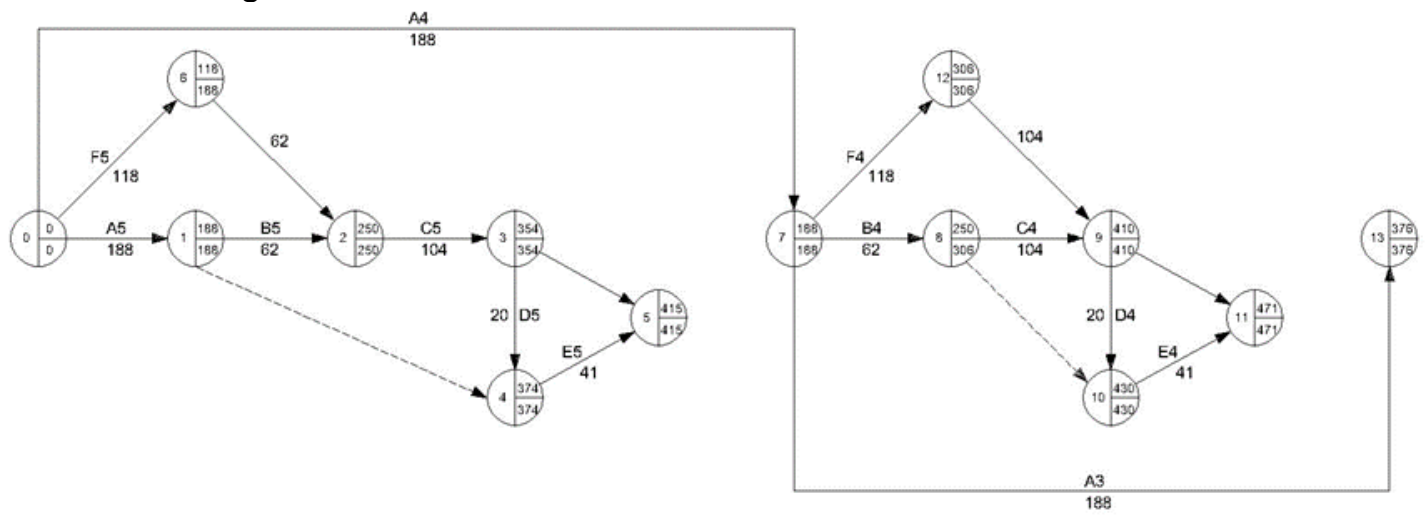




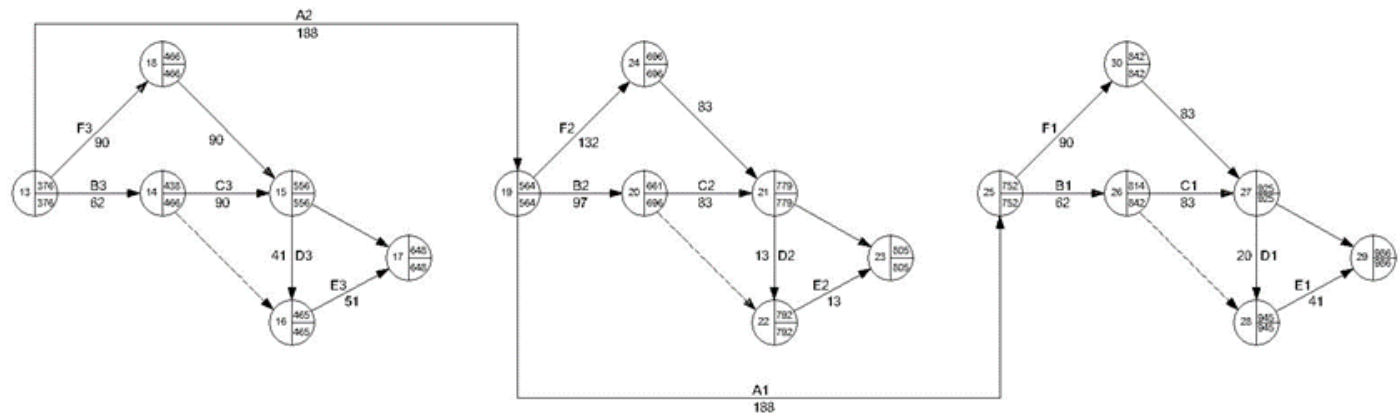

Figure 4.2 Network Duration Diagram for Caspian Surabaya Apartment Project

From the determination of accelerated activities above, the calculation of SPA, SPL and the grace period can be seen in table 4.5:

Table 4.5 Calculation of SPA, SPL and Timelines on the Caspian Tower Apartment Project in Surabaya After Accelerated Activities

\begin{tabular}{|c|c|c|c|}
\hline KODE AKTIVITAS & SPA & SPL & Tenggang Waktu (Slack) \\
\hline A5 & 0 & 0 & 0 \\
\hline B5 & 0 & 0 & 0 \\
\hline C5 & 0 & 0 & 0 \\
\hline D5 & 0 & 0 & 0 \\
\hline E5 & 0 & 0 & 0 \\
\hline F5 & 118 & 188 & 70 \\
\hline A4 & 0 & 0 & 0 \\
\hline B4 & 250 & 306 & 56 \\
\hline C4 & 0 & 0 & 0 \\
\hline D4 & 0 & 0 & 0 \\
\hline F4 & 0 & 0 & 0 \\
\hline A3 & 0 & 0 & 0 \\
\hline B3 & 0 & 0 & 0 \\
\hline C3 & 438 & 666 & 228 \\
\hline D3 & 0 & 0 & 0 \\
\hline E3 & 0 & 0 & 0 \\
\hline F3 & 0 & 0 & 0 \\
\hline A2 & 0 & 0 & 0 \\
\hline B2 & 661 & 696 & 0 \\
\hline C2 & 0 & 0 & 35 \\
\hline D2 & 0 & 0 & 0 \\
\hline E2 & 0 & 0 & 0 \\
\hline F2 & 0 & 0 & 0 \\
\hline A1 & 0 & 0 & 0 \\
\hline B1 & 814 & 842 & 0 \\
\hline C1 & 0 & 0 & 28 \\
\hline D1 & 0 & 0 & 0 \\
\hline E1 & 0 & 0 & 0 \\
\hline F1 & 0 & 0 & 0 \\
\hline & & & \\
\hline
\end{tabular}

\section{Discussion}

From the results of the discussion it can be seen that by using the CPM (Critical Path Method) method obtained the normal duration of project completion is 453 days and the duration of accelerated project completion is 350 days (103 days faster than the duration of normal project completion). There are several activities that accelerate the duration of the 
work, namely the work A1, B1, C1, D1, E1, F1, F4, A5, B5, C5, E5 and F5. The company is better to use the accelerated CPM method because it can optimize the duration of project completion so that the project can be resolved faster than the initial plan.

\section{CONCLUSION}

Based on the assessment of the Tower Caspian Apartment Surabaya project using the CPM (Critical Path Method) method, the following results are obtained:

1. The optimal time to complete the Surabaya Tower Caspian Apartment project using the CPM method is 350 days.

2. Jobs included in the critical path are $A 4, A 3, A 2 \& A 1$ jobs

3. From the results of the study on the Surabaya Tower Caspian Apartment project, the scheduling carried out using the CPM method, the initial difference in duration with the duration of project completion is 105 days

\section{REFERENCES}

Ali, TubagusHaidar. 1995.Prinsip-Prinsip Network Planning.Gramedia. Bandung

Badri, Sofwan. 1997. Dasar-Dasar Network Planning.RinekaCipta. Jakarta

Dannyanti, E. 2010.OptimalisasiPelaksanaanProyekdenganMetodePert dan CPM

(StudiKasusTwin Tower Building PascasarjanaUndip). Skripsi, FT Undip. Semarang.

Ervianto, Wulfram I. 2002. ManajemenProyekKonstruksi. Andi. Yogyakarta

Gray, C., Simanjuntak, P., Lien K.S., Mspaitella, P.F.L., Varley,R.C.G. 2007. PengantarEvaluasiProyek. GramediaPustakaUtama. Jakarta.

Handoko,T.H. 1999. ManajemenPersonaliadanSumberDayaManusia. BPFE. Yogyakarta.

Hayun. 2005. "PerencanaandanPengendalianProyekdenganMetode PERT-CPM :StudiKasus Flyover Ahmad Yani, Karawang".Journal the winners, Vol. 6, No. 2, h. 155-174

Kajatmo, Soetomo. 1977.UraianLengkapMetode Network Planning jilid I, II, III.BadanPenerbitPekerjaanUmum. Jakarta

Levin, Richard I. \&Kirkpatrick Charles A. 1972. PerentjanaandanPengawasandengan PERT dan CPM. Bhratara.Jakarta.

Nagarajan. 2007.Project Management. New Age International Pvt. New Delhi.

Prasetya, Hery\&FitriLukiastuti. 2009.ManajemenOperasi. MediaPressindo. Yogyakarta.

Render, Barry \&Jay Heizer. 2004. ManajemenOperasi. SalembaEmpat. Jakarta. Render, Barry \&Jay Heizer. 2005. Prinsip-prinsipManajemenOperasi. EdisiKetujuh. SalembaEmpat. Jakarta.

Render, Barry \& Jay Heizer. 2006. Operations Management. $8^{\text {th }}$ Edition. Pearson Prentice-Hall Inc. New Jersey.

Ridho,

Rizki\&Syahrizal. 2014. EvaluasiPenjadwalanWaktudanBiayaProyekdenganMetodePERT dan CPM (StudiKasus: ProyekPembangunan GedungKantor BadanPusatStatistikKota Medan di Jl. Gaperta Medan, Sumatera Utara).JurnalTeknikSipilUSU, Vol. 3, No.1.

Sahid, DadangS.S. 2012. ImplementasiCritical Path Method danPERT Analysis padaProyekGlobal Technology for Local Community.JurnalTeknologilnformasidanTelematika, Vol. 5:14-22.

Setiawan, Wahyu. 2011.EvaluasiPenjadwalanProyekDenganMenggunakanMetode CPM (Critical Path Method) danAnalisisKurva "S" paaProyekPengembanganGedungSekolah SMP Barunawati Surabaya oleh PT. BrajaMusti Surabaya.UPN JATIM Institutional Repository

Siswanto. 2007. Operation Research Jilid II.Erlangga. Jakarta.

Soeharto,I. 1999.ManajemenKonstruksidariKonseptualHingga

Operasional. Erlangga. Jakarta. 
Susilo, YayukSundari. 2012.AnalisisPelaksanaanProyekdenganMetode CPM danPERT (StudiKasuspadaProyekPelaksanaanMain Stadium University Riau).JurnalFakultasTeknikSipilUniversitasRiau:1-16.

TaurusyantiDewidanLesmanaMuh. Fikri. 2015.OptimalisasiPenjadwalanJembatan Gender GunaMencapaiEfektifitasPenyelesaiandenganMetode PERT dan CPM pada PT. Buana Masa Metalindo. JMPE (JurnalllmiahFakultasEkonomi) Vol. I, No. 1 Tahun 2015 E-ISSN 2502-5678 